cellular Jayers and forming veins within the cup or cavity formed by the peripodal membrane. To assume its normal definitive position in the imago it is only necessary that it be thrust out through the narrow opening, the mouth of the original invagination of the skin hypoderm. 'This evagination or shifting from apparently inside the body to outsicle occurs at the time of pupation, the wing thereafter lying folded on the ventral thoracic aspect of the pupa.

\section{References.}

Students undertaking the study of the development of the histoblasts will need to refer to detailed accounts of such development as studied and described by reputable entomologists (and zoologists). For an introduction to, or general abstract of our knowledge of this subject (up to I 897 ) see "The Imaginal Discs of Insects," by H. S. Pratt, Psrche, Feb. 1897, vol. 8, no. 250; for a detailed account of the development of the wing discs of a particular insect species see "The Development of the IVings in the Lepicloptera" by W. F. Mercer, Jour. N. Y. Ent. Soc, March 1900, vol. 8, no. 1. For further references see the bibliograplyy given in these two papers.

\section{Histoblasts Showing Externally.}

'The integument of the larva of Holorasia is too opaque to permit the buds to be visible from the outside of the body, and this is the case with most larvae. But in some the thoracic buds may be readily seen from the outsicle, and the gross details of their development followed by simple examination of the exterior of the larvae. This is true for example of the larvae of Chironomus (fig. I, B) and especially of Simutium (fig. I, A). The position and gross appearance of the thoracic buds in Simulium can be seen in young larvae and the growth and the foldings and convolutions of the hypodermal layer followed by examination of successively older larvae. As the larvae of both Simnlium and Chironomus are common all over the country, (Chironomus in ponds and still pools of streams, and Simulium in clear swift water in dense patches on submerged rocks) some acquaintance at least with imaginal buds can be made without either dissection or sectioning.

\title{
LIFE HISTORIES OF NORTH AMERICAN GEOMETRIDAE.-XXV.
}

\author{
BY HARRISON G. DYAR, WASHINGTON, D. C.
}

Cingilia catenaria Cram. The mature larva has been described by llaris, Packard, Coquillett and scudder.
Eggs. Laid loosely and falling to the ground. Elliptical, gently tlattened on two sides, one end distinctly and sharply trun- 
cate, making the egg not much longer than wide; the other end slightly depresined. rounded; truncate end slightly concive. Smooth, uniformly and rather fincly reticulate, the reticulations irregularly hexagonal, slightly raised, subsranular, the areas tat. Truncate cnd only faintly reticulate, the margin a smooth rim, a lark spot at the micropyle. Pale yellowish green, soon turning sordid lilac and darkening still further before hatching. Size $1 . S \times .7 \times .5 \mathrm{~mm}$. The eggs lie on the ground over winter.

Stage I. Head rounded, not bilobed, smooth, wider tham high, clypeus moderate; blackisis, paler and brownish on the fatce; width about .3 min. body normal, cylindrical, segments submoniliform; lather short, feet normal. foint 2 whitish, the rest with broad dersal, warrower but still broad subdorsal and very broad ventral dark bown hands. Tubercles clivated; setac short, dark, with slightly enlarged tips. Segments obscurely, rather numerously annulate. Shields, plates and tubercles blackish. The larra pales with growth, the dorsal band hecomes palcre than the subdursal one and grayish, all faintly green tinted. The dark transverse cervical shield looks detached in the white arca of joint 2 .

Stage $/ 1$. llead about $6 \mathrm{~mm}$. enect, romulca, moderate!y bilobed, the loben tull; clypeus rather high; pale yellow, shining, a gray patch at the vertex of each lobe; mouth brown, the large ocelli black. liody normal, moderate; tubercles elevated, rather large but coucolorous; setae short, dark. Shields all membranous, concolorous. A narrow black subdorsal line, absent on the shields; two quadrate lateral black patches per segment. obscurely joined by obsolete brownish lateral and stiginatal lines; a narrow brown subventral line, himaculate with blackish segmentarily. Obscure geminate, submaculate, brownish ventral line. Fect dusky shaded.

Stage III. Head rounded, pale yetlow with circular black spots on the epicranial setae, over eyes, a line on back of occiput and patches at apex of paraclypeus, clypeus and epistoma; antennae slrort, lahrum mod. erate; width I mm. Body pale yellow, cervical shield and anal plate with four black spots; ley shielal and sides of joint 2 also spottid. Subdorsal line fine, black, not cutting the shields; lateral and atigmaltal lines brown, broken at the spiracles, joined by bisegmental black patclies; traces of a line just below subventral fold; subventral line black submaculate; adrentral line double, brownish. spiracles black in whitish areas. Sigments anmulate, not shining.

Stage $I Y$. llead slightly bilobed, the lobe full laterally, clypeus large, not high, triatnulas, the sutures not cletp but distinct, paraclypeal sutures faint; light yellow with tour round black spots outwardly on each lobe, it spot over ocelli and some smaller brownish ones on clypens; labrum white; width $1.7 \mathrm{~mm}$. Thoracic feet close together, abdominal ones on joints 12 and 13 . loody light yellow, segments about rz-annulate, but somewhat irregularly ; very narrow deep hrown longitudinal lines, the subdorsal distinct, lateral suprastigmatal and stigmatal faint, the two latter connected before and behind each spiracle by a conspicuous black patch; spiracle surrounded by a white patch subventral line just below the subventral ridge faint; a pedal line submaculate in black; two vential lines on each side, rather. distinct. Abchominal feet with brown black spots similar to those on the head. Thoracic feel less distinctly marked with hrown.

Stage $r$. As in the penultimate stage; width of liead $2.4 \mathrm{~mm}$. Sec description of this stage by Scudder (PSrctie, VI, I24, ISgi).

Cocoon an open uet of yellow silk spun among leavis.

Pufa as described by ticudder.

Lavae from Woods 11 oll, Mass., and Bell. port, N. Y. Viggs were sent me from Nonquilt, Mass., by Miss C. G. Soule. The eggs are laid in September and batch the following spring. Larwal stages passed slowly.

Food flant, liaberry (Myrica cerficra). 

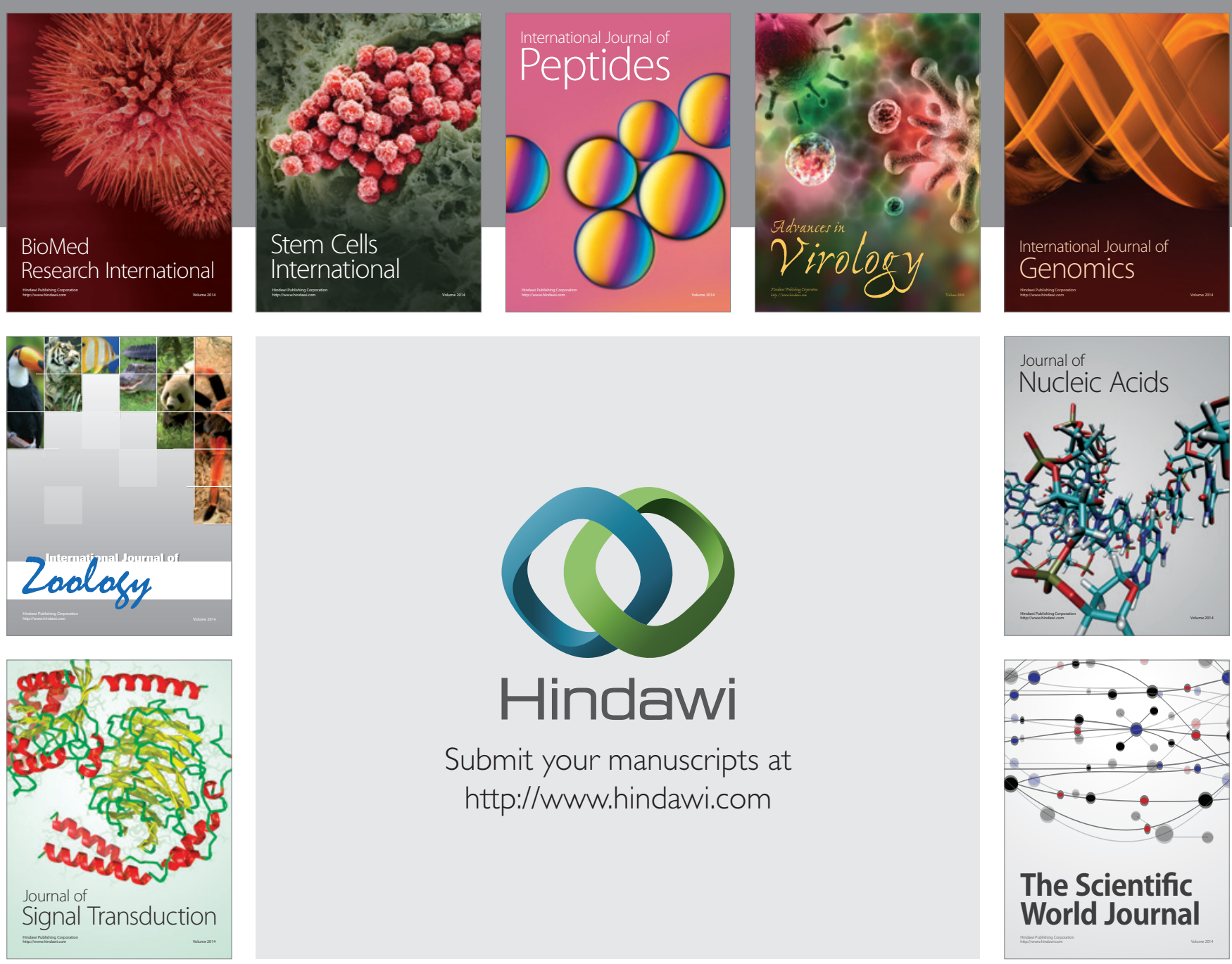

Submit your manuscripts at

http://www.hindawi.com
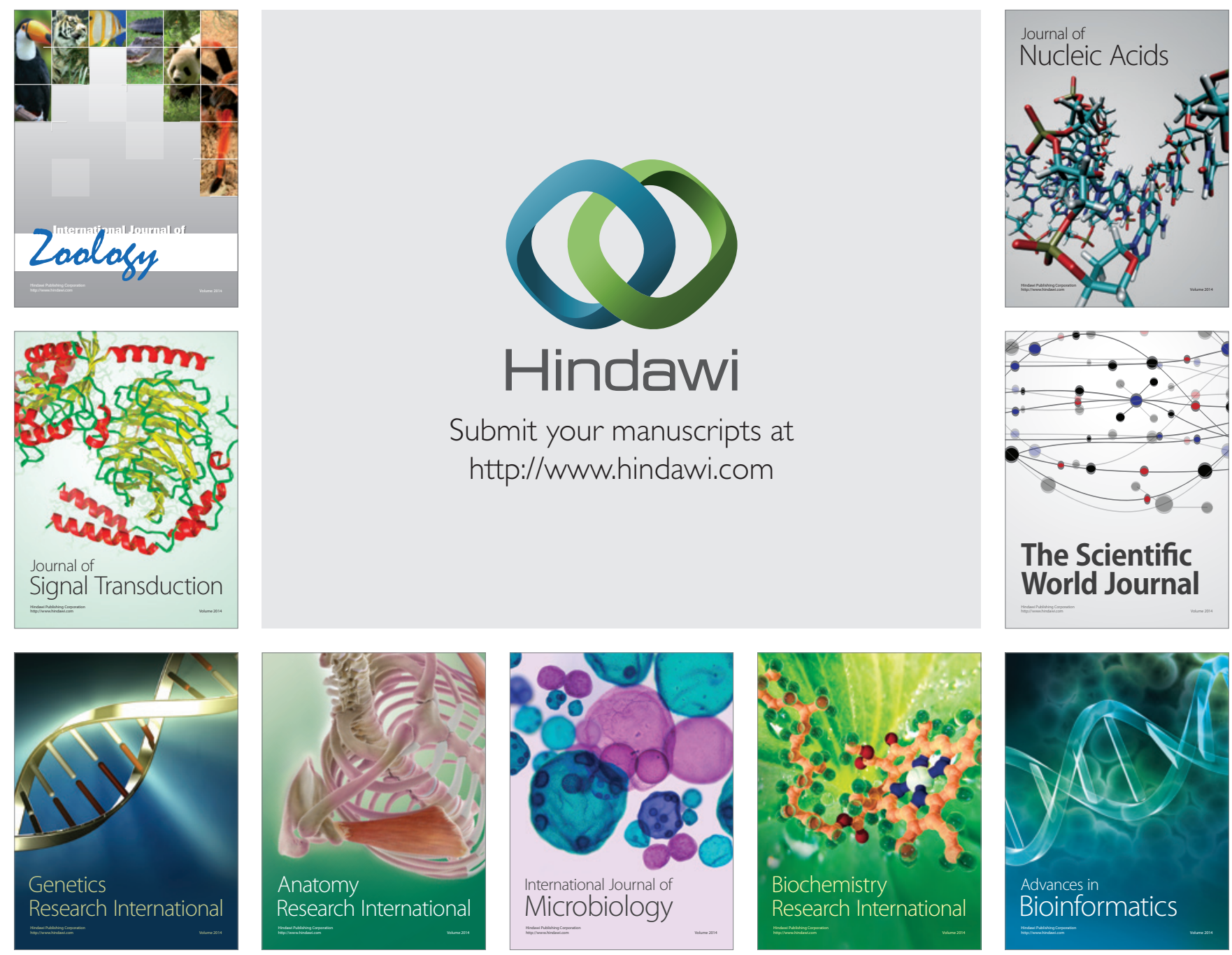

The Scientific World Journal
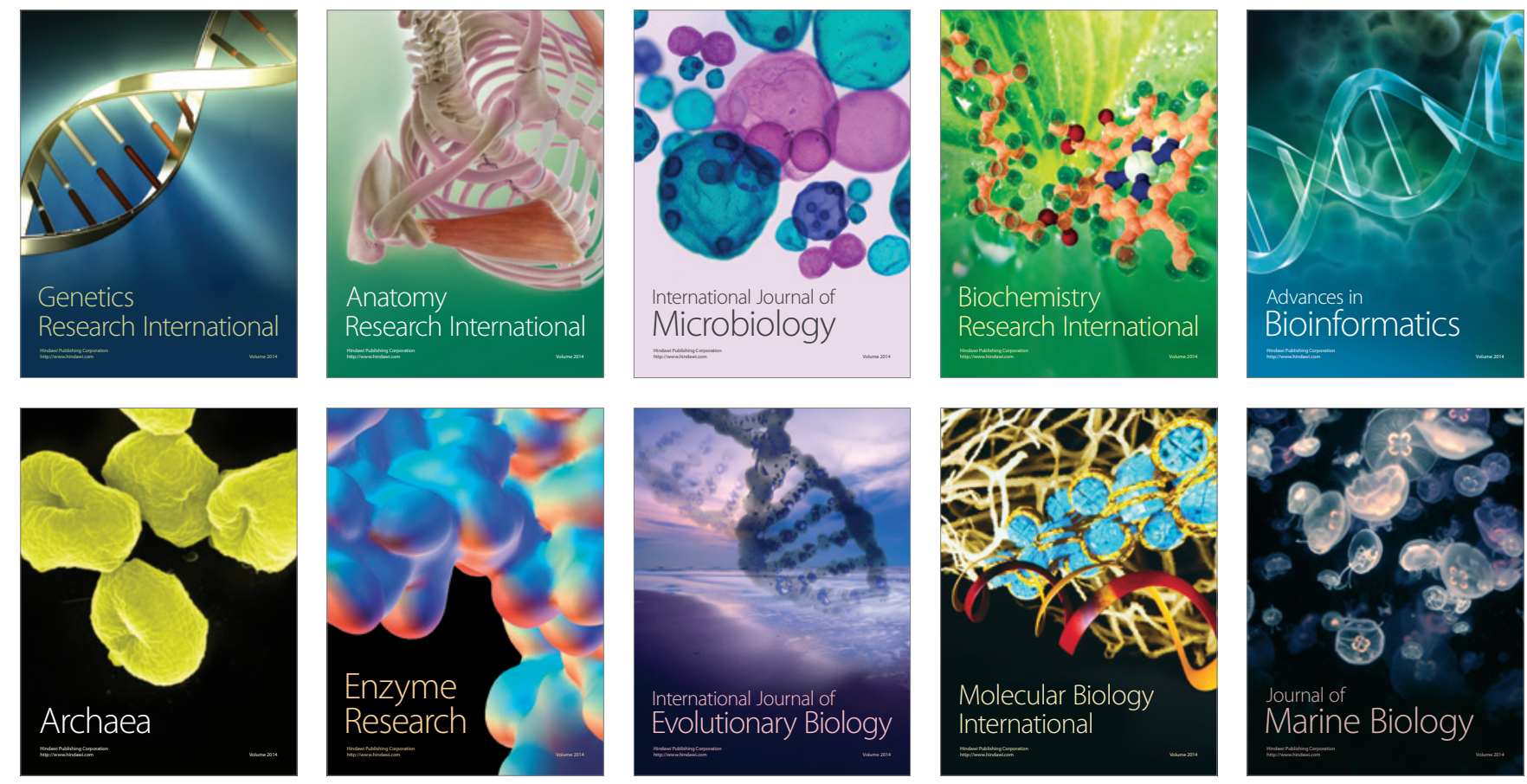